\begin{tabular}{|l|l|l|}
\hline \multicolumn{2}{|c|}{ PublisherInfo } \\
\hline \hline PublisherName & $:$ & BioMed Central \\
\hline \hline PublisherLocation & $:$ & London \\
\hline \hline PublisherImprintName & $:$ & BioMed Central \\
\hline \hline
\end{tabular}

\title{
B-lymphocyte lineage genes
}

\begin{tabular}{|l|c|l||}
\hline \multicolumn{2}{|c|}{ ArticleInfo } \\
\hline \hline ArticleID & $:$ & 4626 \\
\hline \hline ArticleDOI & $:$ & $10.1186 /$ gb-spotlight-20021101-01 \\
\hline \hline ArticleCitationID & $:$ & spotlight-20021101-01 \\
\hline \hline ArticleSequenceNumber & $:$ & 292 \\
\hline \hline ArticleCategory & $:$ & Research news \\
\hline ArticleFirstPage & $:$ & 1 \\
\hline \hline ArticleLastPage & $:$ & 2 \\
\hline \hline & & RegistrationDate : 2002-11-1 \\
\hline ArticleHistory & $:$ & OnlineDate \\
\hline \hline ArticleCopyright & $:$ & BioMed Central Ltd2002-11-1 \\
\hline \hline ArticleGrants & $:$ & \\
\hline \hline ArticleContext & $:$ & 130593311 \\
\hline \hline
\end{tabular}




\section{Jonathan B Weitzman}

Email: jonathanweitzman@hotmail.com

The transcription factors encoded by the E2A gene are critical for the initiation of B-cell development in the bone marrow. In the early Edition of the Proceedings of the National Academy of Sciences, Greenbaum and Zhuang report the identification of target genes regulated by E2A in lymphoid cells. They combined an in vivo murine gene-tagging approach with a chromatin immunoprecipitation (ChIP) assay. Mice were generated that carry a dual affinity-tagged $E 2 A$ knock-in allele. The fusion protein had no affect on lymphoid development, but provides a powerful tool for immunoprecipitation analysis. There was a selective enrichment of known gene targets implicated in B-cell lineage differentiation. Greenbaum and Zhuang cloned immunoprecipitated DNA fragments and were able to identify novel E2A targets. This is the first example of the use if an in vivo murine gene-tagging approach to isolate target genes of an endogenously expressed transcription factor.

\section{References}

1. E2A expression, nuclear localization, and in vivo formation of DNA- and non-DNA-binding species during B-cell development.

2. Proceedings of the National Academy of Sciences, [http://www.pnas.org]

3. Identification of E2A target genes in B lymphocyte development by using a gene tagging-based chromatin immunoprecipitation system, [http://www.pnas.org/cgi/doi/10.1073/pnas.232299999] 